\title{
Library automation initiatives in colleges in malappuram district
}

\author{
Shabna T.P ${ }^{1, *}$, Samna k.k ${ }^{2}$ \\ ${ }^{1}$ Assistant Professor, ${ }^{2}$ Librarian, ${ }^{1}$ Dept. of library and information science, Farook college, Calicut, kerala, ${ }^{2}$ Malabar Polytechnic college, \\ Kottakal, Kerala, India
}

*Corresponding Author: Shabna T.P

Email: shabnasajal@gmail.com

\begin{abstract}
Any work which can be done with the help of automatic machine like computer without any human interface is called automation. Automation of libraries is inevitable in this technological era. The purpose of the study is to find out the status of automation in college libraries, the benefits and problems of automation in college libraries and also to show the importance of automation in libraries. A structured questionnaire is used for collecting the data which are personally distributed. The collected data are classified and analysed. The study found that majority of the college libraries depend on the open source software such as koha because there is no specific fund for automation in any college libraries. College librarians faced problems such as lack of training and lack of sufficient hardware. Librarians noted the benefits like Easy cataloguing and circulation, Time saving, Avoid duplication of records, easier Transaction method, Easy retrieval of documents, Improve quality of library service, Easy library management.
\end{abstract}

Keywords: Library automation, Automation softwares, College libraries.

\section{Introduction}

Library is an indispensable organization of educated and civilized society. The increased growth, use and value of information generated the concept of information society or information oriented society "Libraries may not create civilization; but a civilization cannot exist without them" (Hutchings 65). In other words libraries are treated as the temple of learning where users can find out relevant information from the collection and services to satisfy the thrust of knowledge. But in present era the library has been define as an organization which identifies selection, collection, management, process and dissemination at the right time to the right person. Now Libraries are perceived as places where information is retrieved through sources like Electronic catalogue listings, full-text periodicals and Internet access.

The term automation was first introduced by Harder (1936), who was then with General Motor Company In United States. He defined it initially as "the automatic handling of parts between progressive production processes". The biggest benefit of automation is that it saves labour; however, it is also used to save energy and materials and to improve quality, accuracy and precision.

Automation in libraries has helped the libraries to keep pace with latest development. This has also facilitated accuracy, flexibility and reliability in the library and information centre. Automation of libraries reduces the repetitive work and save time and bring accuracy and speed. It also increases efficiency in technical processing of library materials and improves the efficiency of library administration and manages. Library automation involving creation of database and information retrieval, computerized library network and use of telecommunication for information handling, needs careful and systematic planning. So justification for automation should be logical and convincing. The following reasons are suggested by Dennis Reynolds to justify automation:
1. To increase technical processing efficiency over a manual system.

2. To realize financial savings or containing costs in certain cases where cost savings have been realized through automation.

3. To improve library services.

4. To improve library administration and management.

5. As a response to breakdown of crisis in the existing manual system.

6. To facilitate savings of resources..

The study has reviewed a number of literatures published in national and international publications. "Automation in two Nigerian university libraries" by Adegbore (2002), investigated automation procedures in two Nigerian university libraries and the problems encountered during automation. The research found out that the users' attitude is encouraging and that the automation is still in progress. Other problems include; lack of maintenance, lack of commitment by staff, lack of resources, staff training deficiency. "Automation of shyamlal college library: an experience " by Bajpai (2013), note down eight steps taken in planning for library automation: talked with other librarians, read literature about library automation, visited automated libraries, financing, co-ordination of activities of the automated project ,training for library automation ,develop guidelines for library automation, train library staff in automated methods. This study says that the libraries are automating their internal processes, acquiring and building local databases and making connection in to the internet. The study "library automation with koha" by Egunjobi and Awoyemi (2012) shows that the automation can improve the library relevance to the academic community. It further reveals that library staff enjoys working in an automated environment and the patrons enjoy services renders using an OPAC instead old card catalogue. Krishnamurthy (2001), 
conducted a study about "library automation project: a case study" describes about the project development of computer catalogue of Indian statistical Bangalore centre library. The project aims at automating different facets of library functions right from book acquisition to retrieval services. Various modules such as acquisition system, serial control, cataloguing, circulation and OPAC have been developed using LYBSYS software. According to his study "Library Automation in academic libraries in India: problems and prospects" Singh (2003), said that the things are changing for good. Now university authorities are realizing that there is no way to escape from library automation. They are finding various ways to finance their library automation projects. Librarians are also realizing that they cannot remain indifferent to the change; otherwise they will be labelled out-dated. Existing staff is getting rid of the fear of computerization. They are coming forward to learn and make themselves suitable to face the challenges of the new millennium. Standardization is increasing and the better softwares are available. According to Thapa and Sahoo (2005), two major problems faced by the libraries during automation were serious technical problems, related to software and hardware encountered during installation and working requiring outside technical help, and lack of staff leading to hindrance in computer training staff. The benefits of automation observed in their study are automation increases the use of collection through improved information retrieval and thus increased user satisfaction.

Automating a library is the only way to keep up with new trends to satisfy the end user's to provide pinpointed and exhaustive to information seeker. But there are many problems in library automation like lack of budget, trained manpower etc. Problem of this study is "Library Automation initiatives in colleges in Malappuram district". And this study is limited to Arts and Science colleges in Malapppuram district. For the efficient, effective and scientific development of the information resources and services, the libraries need to be mechanized or automated libraries, because it need efficient or skilled staff and proper fund etc. by conducting this study, can found out the status and problems of Library Automation in Malappuram district, thus libraries can also find solutions for the problem.

\section{The Main Objectives of the study are}

1. To identify the present status of the library automation.

2. To find out which areas of library functions and services are automated.

3. To find out barrier to library automation faced by library staff.

4. To know about the software used in the library automation.

5. To identify the sources of fund for library automation

\section{Research design}

There are different methods used for completion of any research work. College libraries in the arts and science colleges of Malappuram district is the main focus of the study. There are 67 arts and science colleges in Malappuram district affiliated to Calicut University ( 8 Govt, 12 aided, 47 unaided). Census study is conducted. Mainly two type of data collection tool are used. Mailed questionnaire and scheduled questionnaire is used to collect data. The investigator personally visited 40 institutions under the study for meeting with librarians and there conducted a scheduled interview with librarians. And investigator used mailed questionnaire to collect data from colleges which are very far. The filled questionnaires are grouped for the purpose of analysis. For analysis MS-excel is used and percentage method will be used in this study. MLA style manual is used for citation.

\section{Analysis and interpretations \\ Status of library automation in college libraries}

Automation in libraries is very essential in this technological era. Especially in institutions like colleges.

The respondents were asked to note if their library is automated or not. The responses shown in the table below.

\section{Table 1: Status of library automation}

\begin{tabular}{|c|c|c|c|}
\hline Status & Govt & Aided & Unaided \\
\hline Automated & $5(83.33)$ & $9(90)$ & $21(51.22)$ \\
\hline Not automated & $1(16.67)$ & $1(10)$ & $20(48.78)$ \\
\hline
\end{tabular}

(The figures in the brackets show the respective percent)

The data in the table 1 reveals that majority ( 83.33 percent) of government arts and science colleges in Malappuram district have undertaken automation in their library. And majority(90 percent) of aided colleges also automated their library. But in case of unaided colleges only 51.22 percent were automated.

The overall analysis shows that more than half (61.4 percent) of arts and science college libraries in Malappuram district have undertaken automation. But it is found that only half of the unaided college libraries were automated. Because most of the unaided colleges didn't give any importance to their libraries. In some aided colleges, libraries are for namesake.

\section{Extension of library automation}

Libraries may use computers. This question is to know how it extends - fully or partially.

Table 2: Extension of library automation

\begin{tabular}{|l|l|l|l|}
\hline Library Automation & Govt & Aided & Unaided \\
\hline partially automated & $5(100)$ & $3(33.33)$ & $13(61.9)$ \\
\hline fully automated & $0(0)$ & $6(66.66)$ & $8(38.1)$ \\
\hline
\end{tabular}

(The figures in the brackets show the respective percent)

Table 2 reveals that 100 percent of Govt college libraries are partially automated and more than half (61.9 percent) of unaided college libraries are partially automated. But when it comes to aided college libraries, 66.66 percent are fully automated. 
The overall analysis shows that more than half $(60$ percent) of automated colleges are partially automated and a good number (40 percent) are fully automated.

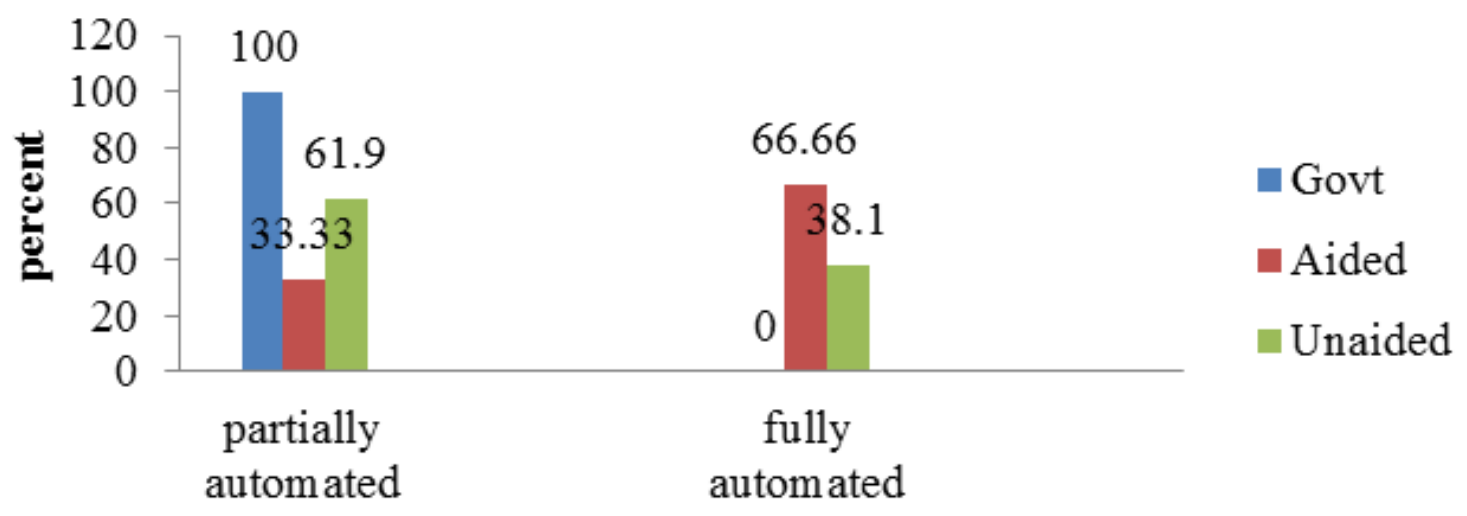

Fig. 1: Extension of library automation

The fig 1 shows the diagrammatic representation of extension of library automation.

\section{Automated modules}

There are many housekeeping operations in a library. For any task, we can use computers. It will reduce the manual work and save time. And it will help libraries to give better services to users. Here investigator check which modules are automated.ie, acquisition, cataloguing, OPAC, circulation, serial control, library administration.

Table 3: Automated modules

\begin{tabular}{|c|c|c|c|}
\hline Modules & Govt & Aided & Unaided \\
\hline Acquisition & $4(80)$ & $7(77.78)$ & $18(85.71)$ \\
\hline Cataloguing & $5(100)$ & $9(100)$ & $21(100)$ \\
\hline OPAC & $5(100)$ & $7(77.78)$ & $13(61.9)$ \\
\hline Circulation & $4(80)$ & $8(88.89)$ & $15(71.43)$ \\
\hline Serial control & 0 & $6(66.67)$ & $10(47.62)$ \\
\hline Library administration & $1(20)$ & $7(77.78)$ & $15(71.43)$ \\
\hline
\end{tabular}

(The figures in the brackets show the respective percent)

Table 3 found that majority of Govt (80 percent), aided (77.78) and unaided (85.71) college libraries are automated acquisition module. 100 percent of Govt, aided and unaided college libraries are automated their cataloguing module. In case of Govt college libraries, 100 percent, 80 percent and 20 percent are automated OPAC module, circulation module and library administration respectively. But no Govt college libraries automated serial control module. Majority (77.78 percent) of aided college libraries and more than half (61.9 percent) of unaided college libraries are automated OPAC. Majority of aided college ( 88.89 percent) and aided colleges (71.43) are automated circulation module. More than half (66.67 percent) of aided and a good number (47.62 percent) of unaided college libraries are automated serial control. Library administration task is computerised majority of aided (77.8 percent) and unaided college (71.43 percent) libraries.

The overall analysis says that 100 percent of automated college libraries automated cataloguing module. Duplication of documents was a big issue in libraries. So libraries used to automate the cataloguing module first. 


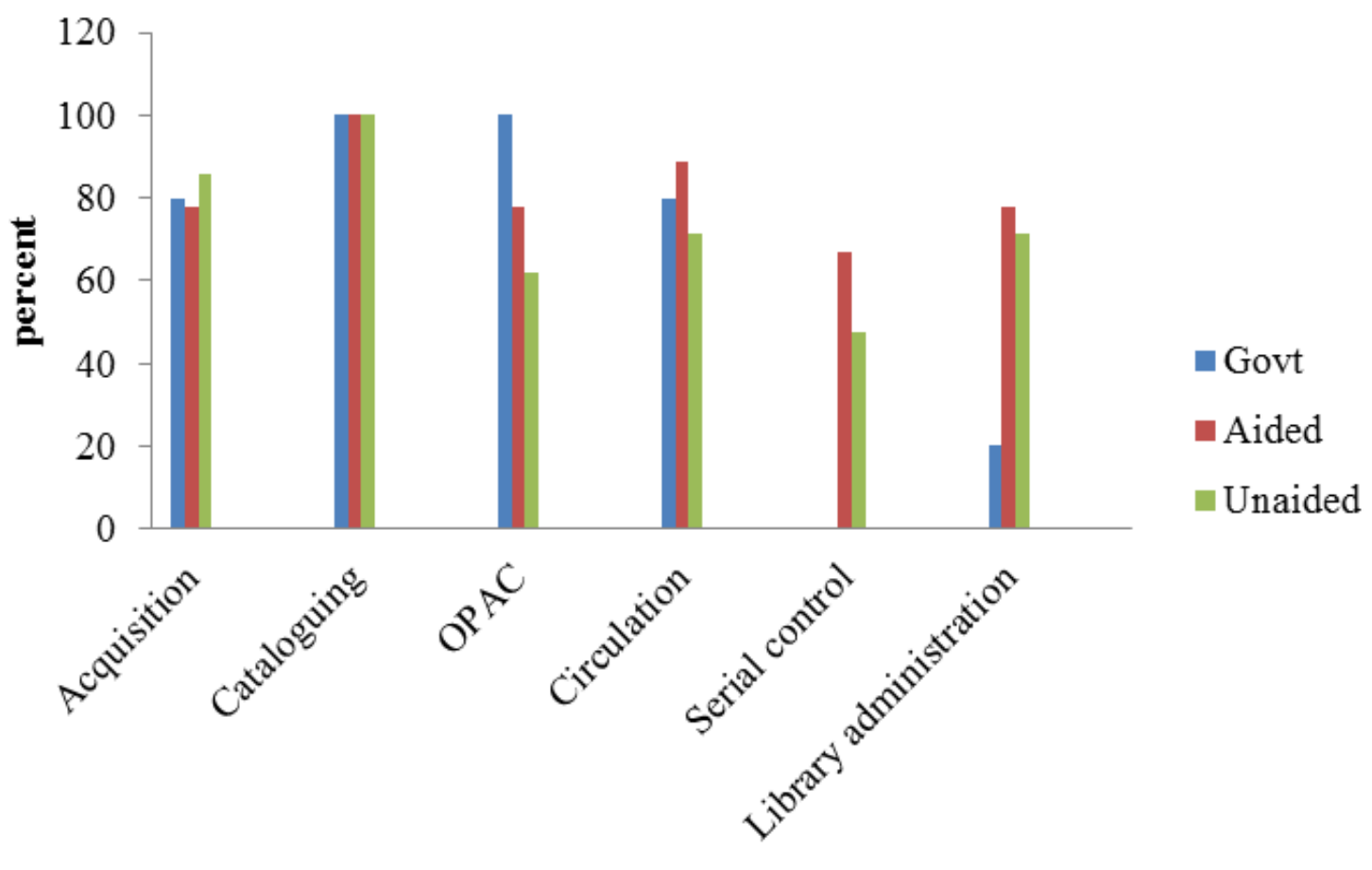

Fig 2: Automated modules

The fig 2 shows the diagrammatic representation of automated modules.

\section{Library automation softwares}

Today, there are many library automation software is available both commercial and open source. This question is to know the library automation software which the libraries are using.

Table 4: Library automation softwares

\begin{tabular}{|c|c|c|c|}
\hline Library automation software & Govt & Aided & Unaided \\
\hline Koha & $4(80)$ & $4(44.44)$ & $15(71.43)$ \\
\hline Book magic & $1(20)$ & $5(55.56)$ & $4(19.05)$ \\
\hline Newgenlib & 0 & 0 & $1(4.76)$ \\
\hline Libsoft & 0 & 0 & $1(4.76)$ \\
\hline
\end{tabular}

(The figures in the brackets show the respective percent)

Table 4 reveals about the library automation softwares which the college libraries in Malappuram district used. Majority of Govt (80 percent) and unaided college (71.43 percent) libraries are used koha library automation software where only 44.44 percent of aided college libraries used koha. Only few (20 percent) of govt and a few (19.05 percent) of unaided college libraries used book magic. But more than half (55.56 percent) of aided college libraries used book magic. Only a very few (4.76 percent) of unaided colleges used newgenlib and libsoft. And no Govt and aided college libraries used newgenlib and libsoft.

The overall analysis says that more than half (65.71 percent) of college libraries used the library automation software koha. Koha is an open source Integrated Library system. It is used widely, because its original source code is made freely available and may be redistributed and modied.

\section{Type of software}

There are two types of library automation softwares- commercial and open source software. This question was intended to know which type of software is used more. 
Table 5: Type of software used

\begin{tabular}{|c|c|c|c|}
\hline Type of software & Govt & Aided & Unaided \\
\hline Commercial software & $1(20)$ & $5(55.56)$ & $5(23.81)$ \\
\hline Open source software & $4(80)$ & $4(44.45)$ & $16(76.19)$ \\
\hline
\end{tabular}

(The figures in the brackets show the respective percent)

Table 5 shows that few of govt (20 percent)and unaided (23.81 percent) and more than half (55.56 percent) of aided college libraries used commercial library automation software where majority of Govt(80 percent), unaided (76.19 percent)and above a good number (44.45 percent) of aided college libraries used open source library automation software.

The overall analysis shows that more than half ( 68.57 percent) of college libraries used open source library automation software. College libraries have restricted fund. So they choose open source software as it doesn't need more money for installation and updating

\section{Problems with library software}

This question was to understand the problems of different library automation softwares used.

Table 6: Problems with library software

\begin{tabular}{|c|c|c|c|c|}
\hline Problems & Koha & Book magic & Newgenlib & Libsoft \\
\hline Lack of vendor's availability & 0 & $1(10)$ & 0 & 0 \\
\hline Lack of trained staff & $14(60.87)$ & $2(20)$ & $1(100)$ & 0 \\
\hline Difficult to use & 0 & 0 & 0 & 0 \\
\hline Lack of administrative support & $1(4.35)$ & 0 & 0 & 0 \\
\hline Lack of user friendliness & 0 & $1(10)$ & 0 & 0 \\
\hline Customer service & 0 & $2(20)$ & 0 & 0 \\
\hline No demo training & 0 & 0 & 0 & 0 \\
\hline
\end{tabular}

(The figures in the brackets show the respective percent)

The above table 6 shows that more than half 60.87) percent of koha software used college libraries faced lack of trained staff and a very few (4.35 percent) faced lack of administrative support. In case of book magic, a very few (10 percent) faced lack of vendors availability and lack of user friendliness. And few (20 percent) faced lack of trained staff and customer service problem. Newgenlib also face lack of trained staff.

The overall analysis reveals that a good number (48.57 percent) of automated college libraries faced the problem of lack of trained staff. That is because Most of the college libraries were worked with one staff.

\section{Need to Change the software}

There are many automation softwares available. Opensource softwares didn't need more fund to install. So there are chances to change from commercial to open source.

Table 7: Need to change the software

\begin{tabular}{|c|c|c|c|c|}
\hline Need to change the software & Koha & Bookmagic & Newgenlib & Libsoft \\
\hline Yes & 0 & $3(30)$ & 0 & 0 \\
\hline No & $23(100)$ & $7(70)$ & $1(100)$ & $1(100)$ \\
\hline
\end{tabular}

(The figures in the brackets show the respective percent)

The table 7 shows that no koha, newgenlib and libsoft users want to change the software. But a good number (30 percent) of book magic used college libraries need to change the software.

The overall analysis says that only a few ( 8.57 percent) of college libraries want to change the automation software. And they want to change from book magic to koha as koha is freely available and can modify the source code suitable to library.

\section{Staffs}

Librarianship is a professional job. And there are courses like MLISc and BLISc. So this question was to know how many professionals' worked in libraries with compared to non professionals. 
Table 8: Staffs

\begin{tabular}{|c|c|c|c|}
\hline Staff & Govt & Aided & Unaided \\
\hline Professional & $6(60)$ & $13(43.33)$ & $21(48.83)$ \\
\hline Nonprofessional & $4(40)$ & $17(56.67)$ & $22(51.16)$ \\
\hline
\end{tabular}

(The figures in the brackets show the respective percent)

The above table 8 reveals that more than half (60 percent)of staffs in Govt college libraries are professional. A good number of staffs are professional in aided and unaided colleges (43.33 percent and 48.83 percent).

The overall analysis shows that more than half (51.8 percent) of staffs in college libraries in Malappuram district are non professional.

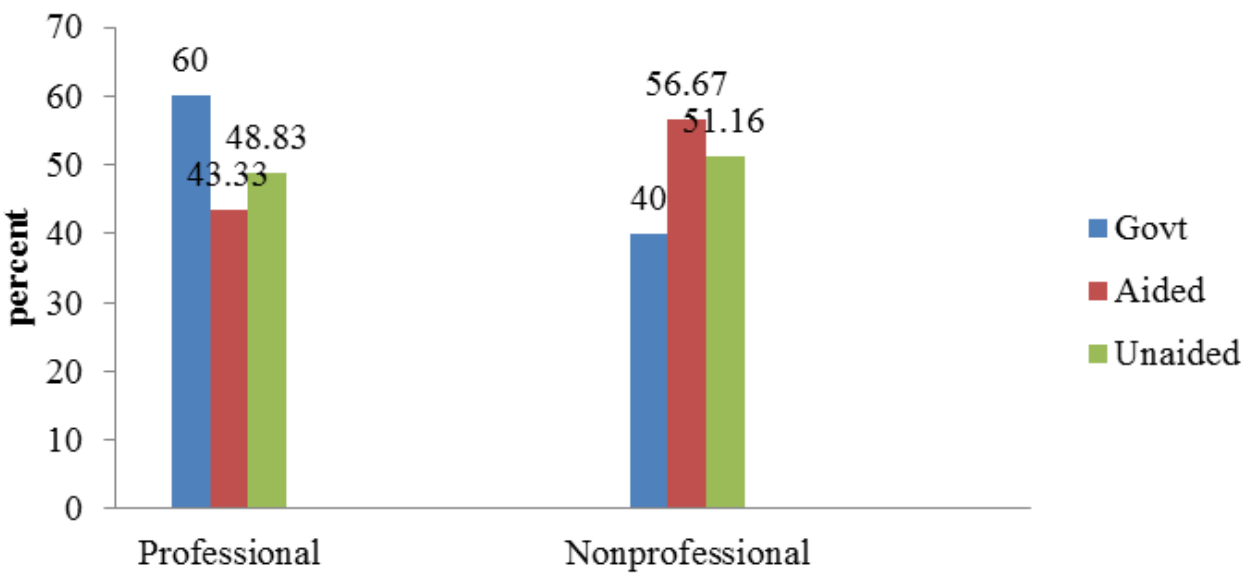

Fig 3: Staffs

The fig shows the representation of staffs.

\section{Problems faced by staff}

Staffs may felt problems while working. Because the technologies changing day by day. So the librarians were asked to show their problems while working and the responses are summarized in the table 9.

Table 9: Problems faced by staffs

\begin{tabular}{|c|c|c|c|}
\hline Problems & Govt & Aided & Unaided \\
\hline Technological barrier & $1(20)$ & $6(66.67)$ & $5(23.81)$ \\
\hline Lack of training & $4(80)$ & $6(66.67)$ & $13(61.9)$ \\
\hline Lack of hardware & $2(40)$ & $5(55.56)$ & $15(71.42)$ \\
\hline Lack of administrative support & 0 & $1(11.11)$ & $6(28.57)$ \\
\hline
\end{tabular}

(The figures in the brackets show the respective percent)

The above table shows that, in Govt few (20 percent) faced technological barrier, majority ( 80 percent) faced lack of training and a good number (40 percent) faced lack of hardware. In aided, more than half (66.67 percent) faced technological barrier and lack of training, (55.56 percent) faced lack of hardware and a very few (11.11 percent) faced lack of administrative support. And in unaided few (23.81 percent) faced the problem technological barrier, more than half (61.9 percent) felt lack of training, majority (71.42 percent) felt lack of hardware and few (28.57 percent) faced lack of administrative support. The overall analysis shows that more than half (65.71 percent) of college library faced lack of training to staff and(62.85) lack of hardware.

\section{Source of fund for library}

In this question, librarians were asked to note the source of fund and the fund for automation if any.

Table 10: Source of fund for library

\begin{tabular}{|c|c|}
\hline Type of college & Source of fund \\
\hline Government & Government \\
\hline Aided & UGC and management \\
\hline Unaided & Management \\
\hline
\end{tabular}


Table 10 says that the source of fund for Govt college libraries is from Govt, for aided college libraries is from UGC and Management and for unaided college libraries is from management fund. All respondents responded that there is no specific fund for automation in college libraries.

\section{Results and discussions}

More than half of arts and science college libraries in Malappuram district have undertaken automation. All the Govt college libraries are partially automated. All the college libraries automated cataloguing module. More than half of college libraries used the library automation software koha. That is most of the colleges select open source library automation software. A good number of automated college libraries faced the problem of lack of trained staff. Some of the college libraries want to change the automation software book magic to koha. More than half of staffs in college libraries in Malappuram district are non professional. College librarians faced the problems like lack of training and lack of hardware. The source of fund for Govt college libraries is from Govt, for aided college libraries is from UGC and Management and for unaided college libraries is from management fund. There is no specific fund for automation in any college libraries. The respondents noted the following problems: Power supply problems, Lack of trained staff, Lack of sufficient hardwares, Technical problems of computer, Technological barrier, Up gradation of software, Non user friendliness, original version of softwares, Lack of sufficient fund and Software problems. The librarians noted the benefits of automation. that areSimplicity and easiness, Quick updation of records, Easy cataloguing and circulation, Time saving, Avoid duplication of records, Transaction method is easy, Purification of collection, Easy retrieval of documents, Manual works reduced, Collection of fine is easy, Improve quality of library service, Easy reports of works, Easy library management.

With the help of the analysis, the investigator wishes to put forwards the following suggestions for improving:

1. Give adequate training to the library staffs regarding automation,

2. Fund should be allocated for Library Automation,

3. Appoint more professional staff Instead of nonprofessional staff,

4. Give awareness programmes to the non automated colleges about the need and significance of automation in libraries.

\section{Conclusion}

Libraries are notorious for collecting and storing information in society. An endless supply of information is continuously generated in these institutions and anyone can readily access it regardless of time and space. But the successful process of library automation has many issues and problems are: need proper planning, sound budget, lack of awareness of standard format, skilled or trained manpower etc.

From the findings of the study, the investigator understands that there is good number of not automated college libraries in this IT era. Cataloguing module is the only module which all college libraries were automated. More libraries used the library automation software KOHA as it is a open source software and because of the same reason, some wanted to change their automation software to KOHA. Library staffs need adequate training and libraries need more hardwares and fund for betterment of library.

Librarians must analyze their automation needs and plan the selection and implementation of automation system (Information and communication Technology) that support the mission and priorities of the institution for efficient and improved services to the patron. It is truth that the things are changing for good. Now college libraries are realizing that there is no way to escape from library automation and also, they cannot remain indifferent to the change, otherwise they will be labelled outdated.

\section{References}

1. Adegbore, A M, "Automation in Two Nigerian University Libraries”, N.p, 2002, web. 20 Jan 2017.

2. Bajpai, V K, "Automation of Syamlal college library: an experience", Library progress, 33.2 (2014): 251-260. Print

3. Egunjobi, R A and R AAwoyemi, "Library automation with Koha", "Library hi-tech news", emerald, 2012, web. 10 jan 2017.

4. Hutchings,F.G.B, "Librarianship; a shortmanual", Oxford: Oxford University Press,2000. Print. Khanna, J K, "library and society", 2nd ed. New Delhi: EssEsspublications, 1994. Print.

5. Mishra, Ajay Shankar, "Library automation: issues challenges and remedies", "Times int j res", ,N.p, N.d, web. 10 Jan, 2017.

6. Naveen, C L and Nagesh R, "Status and problems of library automation in Govt first grade colleges of Hassan district,Karnataka: A study", Int j libr inf sci, N.p, N.d, web. 10 Jan, 2017.

7. Krishnamurthy, M, "Library automation project: A case study", KelproBullettin, 5.2 (2001): 15-18. Print.

8. Singh, Yogendra, "Library automation in academic libraries in India: problems and prospectus",N.p, 03/03/2004, web. 10 Jan 2017.

9. Thapa, Neelam and K C Sahoo, "problems and prospects of Automation:A survey of special libraries in Bhopal", Libr Progress(International), 25.1 (2005): Print.

How to cite this article: Shabna T.P, Samna k.k Library automation initiatives in colleges in malappuram district, Indian j Libr Sci inf techno. 2018;3(2):94100 